\title{
Herpesvirus hominis antibodies among children and young adults in Ibadan
}

\author{
A. O. SOGBETUN, D. MONTEFiore, AND C. N. ANONG \\ From the Department of Medical Microbiology, University College Hospital, Ibadan, Nigeria
}

SUMMARY A total of 422 sera collected from children and young adults living in Ibadan, Nigeria, has been examined for the presence of antibodies to type 1 and type 2 herpesvirus hominis. Type 1 antibodies were rapidly acquired from the age of 1 year onwards, reflecting the relatively poor living standards and the overcrowded accommodation among the population studied. Type 2 antibodies were acquired between the ages of 3 and 5 years. It is suggested that non-venereal spread of the virus must be responsible; prolonged survival of the virus on fomites, owing to the high environmental humidity, possibly accounts for this.

\section{Introduction}

Several of the herpesviruses which infect animals possess oncogenic properties, and a causal association is suspected between infection with herpesvirus hominis type 2 (HVH-2) and later development of carcinoma of the uterine cervix (Rapp, 1973), which is one of the commonest malignant conditions seen in women in Ibadan (Attah and Hendrickse, 1977). Genital herpes, almost exclusively due to HVH-2 (Amstey, 1973), is being diagnosed with increasing frequency (WHO, 1974), although it is not clear whether there is a true increase in the incidence of infection or whether the increased frequency in diagnosis results from better diagnostic methods. However, much of the evidence which has brought HVH-2 under suspicion as a possible cause of cervical carcinoma derives from seroepidemiological studies, and there is, therefore, considerable interest in the incidence of infection with this virus in different parts of the world.

There is little information available concerning genital herpetic infection in Nigeria, although preliminary serological studies by Adelusi et al. $(1975,1977)$ suggest that approximately $13 \%$ of healthy young women may have experienced previous infection with the virus. Genital herpes infection is not often seen in the acute stage in hospital practice, but this may be due to the fact that where medical facilities are relatively scarce only patients with the most extensive and painful

Address for reprints: Dr A. O. Sogbetun, Department of Medical Microbiology, University College Hospital, Ibadan, Nigeria

Received for publication 5 July 1978 lesions attend. Those patients with milder lesions are likely to treat themselves or seek advice from native practitioners.

Patients acquire herpesvirus hominis infection as a result of close personal contact (Nahmias and Roizman, 1973). This contact is generally nonsexual in the case of the type 1 virus and sexual in the case of the type 2 virus. The evidence for considering $\mathrm{HVH}-2$ infection as a sexually transmitted disease is based on the finding that antibodies to the virus are virtually absent from children below the age of puberty (Nahmias et al., 1970) and among celibate communities such as nuns (Nahmias and Roizman, 1973), and also that antibodies occur most frequently among the sexually promiscuous (Duenas et al., 1972). In addition, type 2 virus is isolated from approximately $90 \%$ of genital lesions, while type 1 virus is isolated from a similar proportion of 'above-the-waist' infections (Dowdle et al., 1967).

Antibodies to type 1 virus start to increase in frequency from about 6 months of age, once maternally acquired immunoglobulins have disappeared. The rate of acquisition, and the final proportion of sera found to contain type 1 antibodies, varies with the population studied. Both variables tend to be higher among populations of low socioeconomic status (Smith et al., 1967), probably reflecting greater opportunities for spread of the virus where living conditions are crowded.

These data, however, derive from populations studied in the developed countries, and the distribution and incidence of antibodies to the two types of virus may not necessarily follow the same pattern 
among people living under the very different conditions of a developing tropical country. Under the latter conditions type 2 virus could probably spread more readily by non-venereal routes (Poste et al., 1972; Roome et al., 1975), and this might be reflected by an increased incidence of type 2 antibody among the younger age groups.

The present paper reports the incidence of antibodies to herpesvirus hominis types 1 and 2 among children and young adults living in Ibadan, a large city in the humid tropics. The population samples in the younger age groups included children attending clinics at the University College Hospital, Ibadan, for conditions unrelated to herpetic infection while those in the older age groups included healthy school pupils.

\section{Material and methods}

\section{SERA TESTED}

Fifty-two samples of sera were collected from children in the age group 0-3 months; of these 29 were cord blood samples obtained in the labour wards of the hospital and 23 were capillary blood samples from children attending clinics for conditions unrelated to herpesvirus infection. In the latter instances, approximately $0.5 \mathrm{ml}$ of blood was collected by heel or finger prick. Sera were separated and stored at $-20^{\circ} \mathrm{C}$ before being tested.

In the older age groups venous blood, or in younger children capillary blood, samples were similarly collected and the sera separated and stored at $-20^{\circ} \mathrm{C}$ before being tested. In the older age groups samples were obtained from healthy school pupils.

In all cases, the children were broadly representative of the socioeconomic level of the majority of the Ibadan population. Serum samples were not collected from children of parents in the higher socioeconomic groups.

\section{NEUTRALISATION TESTS}

Serum samples were examined by the microneutralisation test in disposable flat-bottomed plastic tissue culture plates. Serum titrations were carried out against known type 1 and type 2 virus strains. Control sera from rabbits initially immunised against the respective virus were included in each batch of tests. Both the type 1 and the type 2 antisera were first tested 78 times against each type of virus, the $\mathrm{pN}$ values determined, and the ratio pN type $2: \mathrm{pN}$ type 1 calculated. This ratio, multiplied by 100 , was termed the $\mathrm{NpN}$ value.

The method of testing the sera and calculating the $\mathrm{NpN}$ values was based on that of Pauls and Dowdle
(1967) with the modifications described previously by Roome et al. (1975). The initial serum dilution in each case was $1 / 10$, as higher serum concentrations tended to be toxic to the Vero cells used. Results for sera not showing neutralisation at a 1/10 dilution were regarded as negative.

The mean $\mathrm{NpN}$ value for each serum sample was obtained together with the standard deviation for each set of values. For the type 1 antiserum the mean $\mathrm{NpN}$ value was 78.5 while for the type 2 antiserum the mean $\mathrm{NpN}$ value was 113.2 , with standard deviations of 6.5 and 15.2 respectively. When the results of test sera were interpreted, those which gave $\mathrm{NpN}$ values identical with those of the control sera (standard deviation \pm 1 ) were regarded as containing only a single antibody of the appropriate type. Those sera with $\mathrm{NpN}$ values which fell between the control values (standard deviation \pm 1 ) were considered to contain both types of antibody.

\section{Results}

The results for the total of 422 children and young adults examined are shown in the Table. The numbers of subjects in each age group are indicated, together with the number of serum samples containing either type 1 antibody, type 2 antibody, or no detectable antibody. Where a serum sample contained both types of antibody it has been included in both categories. Of the 422 subjects 210 were female and 212 were male; the findings did not differ for the two sexes in any age group and so the results for both sexes have been combined.

In the $0-3$ month age group, $86 \%$ of sera showed the presence of type 1 antibodies. This percentage fell to $6.9 \%$ in the 4-11 month age group, reflecting waning maternal antibody, but then rose rapidly from 1 year of age onwards to reach a peak of between $70 \%$ and $83 \%$ in the teenage period.

Type 2 antibodies were present in approximately $6 \%$ of sera in the youngest age group, with the incidence falling to only $1.6 \%$ by 3 years of age. Between 3 and 5 years, however, there was a rapid acquisition of type 2 antibodies, with the incidence rising to approximately $11 \%$; only a slight further increase occurred in the older age groups.

\section{Discussion}

There have been relatively few published reports on the age-related acquisition of antibodies to herpesvirus hominis, and in the earlier studies the methods used did not distinguish between antibodies to the two different types of virus. Thus Smith et al. (1967) noted that in the Edinburgh population antibodies 
Table Incidence of antibodies to herpesvirus hominis in sera from children and young adults

\begin{tabular}{|c|c|c|c|c|c|c|c|}
\hline \multirow{3}{*}{ Age group } & \multirow{3}{*}{ No. of sera tested } & \multicolumn{4}{|c|}{ Positive herpesvirus hominis antibodies } & & \\
\hline & & \multicolumn{2}{|c|}{ Type 1* } & \multicolumn{2}{|c|}{ Type 2* } & \multicolumn{2}{|c|}{ No. antibodies } \\
\hline & & No. & $\%$ & No. & $\%$ & No. & $\%$ \\
\hline $\begin{array}{l}0-3 \text { months } \\
\text { 4-11 months } \\
1-2 \text { years } \\
3-5 \text { years } \\
6-10 \text { years } \\
11-15 \text { years } \\
16-20 \text { years }\end{array}$ & $\begin{array}{l}52 \\
29 \\
64 \\
64 \\
49 \\
82 \\
82\end{array}$ & $\begin{array}{r}45 \\
2 \\
17 \\
36 \\
37 \\
68 \\
58\end{array}$ & $\begin{array}{r}86 \cdot 5 \\
6 \cdot 9 \\
26 \cdot 6 \\
56 \cdot 3 \\
75 \cdot 5 \\
82 \cdot 9 \\
70 \cdot 7\end{array}$ & $\begin{array}{r}3 \\
1 \\
1 \\
7 \\
7 \\
10 \\
10\end{array}$ & $\begin{array}{r}5 \cdot 8 \\
3 \cdot 5 \\
1 \cdot 6 \\
10 \cdot 9 \\
14 \cdot 3 \\
12 \cdot 2 \\
12 \cdot 2\end{array}$ & $\begin{array}{r}6 \\
26 \\
46 \\
22 \\
7 \\
10 \\
16\end{array}$ & $\begin{array}{l}11 \cdot 5 \\
89 \cdot 7 \\
71 \cdot 9 \\
34 \cdot 4 \\
14 \cdot 3 \\
12 \cdot 2 \\
19 \cdot 5\end{array}$ \\
\hline
\end{tabular}

*Sera containing both types of antibody are included in both columns

to herpesvirus hominis were present in $100 \%$ of samples from the 0-3 month age group, with the incidence falling to a low point of $19 \%$ between 6 and 12 months and thereafter rising gradually to around $70 \%$ by the age of 20 years. These workers particularly noted the effect of socioeconomic status on the incidence of herpesvirus hominis antibodies, with the proportion of sera giving positive results decreasing as living standards improved. More recently Terzin and Masic (1976), in Yugoslavia, noted a similar pattern of antibody response to type 1 infection, although among their population infection seemed to be acquired at a much earlier age than in Edinburgh. Our findings in Ibadan are similar to those in Yugoslavia and may be taken to reflect early acquisition of herpesvirus infection as a result of relatively unsatisfactory living conditions and consequent overcrowding.

Nahmias et al. (1970) studied the acquisition of antibodies to the two types of virus in an American population. Type 1 infections were acquired less rapidly than in Yugoslavia or in Ibadan-presumably because of a higher standard of living and better accommodation. Type 2 antibodies were detectable, once maternally acquired immunoglobulins had waned, only in children over 14 years old, a finding that has been much quoted in support of the view that type 2 infection is mostly spread by sexual contact. The findings of Duenas et al. (1972) also support this view, since the incidence of type 2 antibodies increased with age and professional experience among the group of prostitutes examined by these workers.

Infection with type 2 herpesvirus hominis is not unknown among young children (Nahmias et al., 1968), although it is apparently very uncommon. In Ibadan, however, our serological evidence indicates that infection with this virus occurs at a young age, with approximately $11 \%$ of sera from children aged between 3 and 5 years containing antibody. These findings resemble the observations of Osoba and Alausa (1974), who found that gonococcal vulvovaginitis in young girls was relatively frequent in Ibadan and that sexual assault did not appear to be responsible. They suggested that the gonococcus was transmitted from older relatives to young children, not only by close personal contact but also by shared towels and bed clothes. This suggestion received support from the findings of Alausa et al. (1977) that while Neisseria gonorrhoeae in simulated exudates was indeed rapidly destroyed by drying (Wilson and Miles, 1975) this process was delayed, and viable gonococci persisted for at least several hours, when the samples were deposited on cloth and exposed to the humid air during the rainy season in Nigeria.

Thus the common habit among the local population of young children sleeping in the same bed as older relatives, as well as sometimes using the same towels and articles of clothing, could well lead to transmission of infection to the young child without the necessity of close or immediate bodily contact.

The possibility of non-venereal spread of herpesvirus hominis type 2 infection has been previously noted by Poste et al. (1972) and Roome et al. (1975), and in Ibadan it seems possible that such spread may be of particular importance. The same situation may exist with regards to the survival of herpesvirus in the tropics as has been previously shown in the case of the gonococcus, and could similarly lead to an increased incidence of HVH-2 infection among young children.

We would like to thank Dr A. P. C. H. Roome for kindly supplying the type strains of virus.

\footnotetext{
References

Adelusi, B., Osunkoya, B. O., and Fabiyi, A. (1975). Antibodies to herpes type-2 virus in carcinoma of the cervix in Ibadan, Nigeria. American Journal of Obstetrics and Gynecology, 123, 758-761.

Adelusi, B., Osunkoya, B. A., and Fabiyi, A. (1977). Sero-epidemiology of herpes type-2 virus and carcinoma of the cervix in Ibadan. African Journal of Medicine and Medical Science, 6, 95-102.

Alausa, K. O., Sogbetun, A. O., and Montefiore, D. (1977). Effect of drying of Neisseria gonorrhoeae in relation to non-venereal infection of children. Nigerian Journal of Paediatrics, 4, 14-18.
} 
Amstey, M. S. (1973). Current concepts of herpesvirus infection in the woman. American Journal of Obstetrics and Gynecology, 117, 717-725.

Attah, E. D., and Hendrickse, M. (1977). Patient dynamics in cancer registration: Ibadan Cancer Registry. Nigerian Medical Journal, 7, 394-396.

Dowdle, W. R., Nahmias, A. J., Harwell, R. W., and Pauls, F. P. (1967). Association of antigenic types of herpesvirus hominis with site of viral recovery. Journal of Immunology, 99, 974-980.

Duenas, A., Adam, E., Melnick, J. L., and Rawls, W. E. (1972). Herpesvirus type 2 in a prostitute population. American Journal of Epidemiology, 95, 483-489.

Nahmias, A. J., Dowdle, W. R., Naib, Z. M., Josey, W., and Luce, C. F. (1968). Genital infection with herpesvirus hominis type 1 and 2 in children. Pediatrics. 42, 659-666.

Nahmias, A. J., Josey, W., Naib, Z. M., Luce, C. F., and Duffey, A. (1970). Antibodies to herpesvirus hominis type 1 and 2 in humans. I. Patients with genital herpetic infection. American Journal of Epidemiology, 91, 539-546.

Nahmias, A. J., and Roizman, B. (1973). Infection with herpes simplex virus 1 and 2. Part III. New England Journal of Medicine, 289, 781-789.

Osoba, A. O., and Alausa, K. O. (1974). Vulvovaginitis in Nigerian children. Nigerian Journal of Paediatrics, 1, 26-32.
Pauls, F. P., and Dowdle, W. R. (1967). A serologic study of herpes virus hominis strains by micro-neutralisation tests. Journal of Immunology, 98, 941-947.

Poste, G., Hawkins, D. F., and Thomlinson, J. (1972). Herpesvirus hominis infection of the female genital tract. Obstetrics and Gynecology, 40, 871-890.

Rapp, F. (1973). Question: Do herpesviruses cause cancer? Answer: of course they do! Journal of the National Cancer Institute, 50, 825-832.

Roome, A. P. C. H., Montefiore, D., and Waller, D. (1975). Incidence of herpesvirus hominis antibodies among blood donor populations. British Journal of Venereal Diseases, 51, 324-328.

Smith, I. W., Peutherer, J. F., and MacCallum, F. O. (1967). The incidence of herpesvirus hominis antibody in the population. Journal of Hygiene (Cambridge), 65, 395-408.

Terzin, A. L., and Masic, M. G. (1976). Age specific incidence of neutralisation antibodies of herpes simplex virus. Journal of Hygiene (Cambridge), 77, 155-160.

Wilson, G. S., and Miles, A. A. (1975). Topby and Wilson's Principles of Bacteriology, Virology and Immunity. Sixth edition p. 688. Arnold: London.

World Health Organization (1974). Herpes simplex. Weekly Epidemiological Record, 42, 352. 